\title{
Reasonable Value and the International Organization of Labor Rights
}

\section{Richard Mclntyre and Yngve Ramstad}

\section{Q OpenEdition \\ 1 Journals}

\section{Electronic version}

URL: http://journals.openedition.org/ei/724

DOI: 10.4000/ei.724

ISSN: 2553-1891

\section{Publisher}

Association Économie et Institutions

\section{Printed version}

Date of publication: 1 June 2003

Number of pages: 83-109

ISSN: 1775-2329

\section{Electronic reference}

Richard McIntyre and Yngve Ramstad, « Reasonable Value and the International Organization of Labor Rights », Économie et institutions [Online], 2 | 2003, Online since 31 January 2013, connection on 20 April 2019. URL : http://journals.openedition.org/ei/724; DOI : 10.4000/ei.724 


\title{
Reasonable Value and the International Organization of Labor Rights
}

\author{
Richard McIntyre and Yngve Ramstad, Department of \\ Economics and Schmidt Labor Research Center, University of \\ Rhode Island, Kingston RI 02881, USA
}

\section{Introduction}

International economic integration has increased since the 1970s. Those familiar

with the work of Karl Polanyi have not been surprised that integration has brought forth protest and critique. The movement of the market into new areas and aspects of social life stimulates society to protect itself against the market's destabilizing effects (Polanyi, 1944). The decline of the labor movement in the US and some European countries has been accompanied by new organized labor movements in industrializing countries such as Poland, South Africa, Brazil and South Korea (Silver, 1994).

Integration has occurred not only amongst similar societies, as in Europe, but among societies whose living standards, social norms, and standard economic practices differ wildly. This has raised a number of problems, most especially concerning the rights of labor.

Critics of "globalization" have argued that "core" labor rights should be written into regional and multilateral trade agreements. "Free traders" argue that setting such standards prohibits the very differences that are the basis of trade. Universal labor standards treat the "cheap labor" that is the comparative advantage of the poor countries as something to be outlawed. If labor rights are an issue at all they should be dealt with by the International Labor Organization, not in trade agreements. The critics find this less than satisfactory, as the ILO has no enforcement capability.

We argue that the ILO may in fact be an appropriate body for dealing with labor rights, though not for the reasons that the "free traders" stand on. Rather, the ILO, as an explicitly tripartite organization, embodies the problem solving principles of John R. Commons. Commons argued that labor (and other) disputes could not be resolved by reference to general principles, such as costbenefit analysis. Resolution required that all interested parties have a seat at the bargaining table, where they could establish "reasonable value."

There are problems in applying this approach internationally. Neither the principles of tripartism nor the presumption of "core" 
labor rights is well established in all member countries. The ILO lacks the economic sanctions and the ability to threaten violence that establishment of truly international labor norms would require. But it is possible that incorporating ILO findings in national decision making may promote the ILO as an authoritative figure. In any case, in its core values, organizational structure, and understanding of economic processes, the ILO is consistent with Commons' theoretical standpoint, his theory of value, and his analysis of labor markets.

We begin with a brief discussion of existing perspectives on international labor rights. We then develop the Commons approach. In the last section we examine the evolution of the ILO and its relationship to Commons' standpoint, theory of reasonable value, and analysis of labor markets. We consider some of the difficulties in creating reasonable value and authoritative institutions internationally.

\section{Economics of International Labor Rights}

The world economy is not nearly as integrated as some of the more celebratory proponents of globalization imply: national borders still inhibit the movement of money, capital and especially people. While formal barriers to trade have declined substantially, international price arbitrage happens slowly, investment portfolios still exhibit substantial home country bias, and severe barriers to the movement of labor are the exception rather than the rule (Rodrik, 2000). Still, as measured by the ratio of exports to gross domestic product, national economies are substantially more integrated today than they were in the post World War II period.

Such integration has had a significant effect on labor market outcomes in the United States. One econometric estimate indicates that increased trade and immigration are responsible for roughly forty percent of the growing wage gap between more and less educated workers (Borjas, Freeman and Katz, 1997). If increased trade competition forces labor saving technological change and makes it easier for management to discipline labor, then the figure is probably much higher (Wood, 1995). International capital mobility reduces workers' bargaining power, subjects them to greater instability of employment and incomes, and forces workers to bear a greater proportion of the non-wage costs of work, such as safe working conditions and health costs (Bronfenbrenner, 2001, Rodrik, 1997). At a broader level, Freeman (1996) estimates that the majority of the increase in income inequality in the United States is due to the "de-institutionalization of wage norms" through increased trade, capital mobility, immigration, declining unionization, and the long term decline in the minimum wage. 
Because social change is a holistic process we would prefer not to get caught up in the debate over which supposedly independent factor is the "most" important in causing increased inequality. In our view there is no statistical test by which we could "prove" that increased international economic integration is the most important. But the more popular view amongst policymakers technological change is the culprit - has surprisingly little supporting evidence, and seems to be more wishful thinking than careful analysis (Rodrik, 1997, p.16). ${ }^{1}$

Even if we can establish that international integration has negative effects on labor market outcomes, this does not demonstrate that labor rights have been affected, as rights deal with process not outcome. "Core" labor rights as defined by the International Labor Organization include freedom of association, right to organize and bargain collectively, right to refuse forced labor, right to freedom from child labor, and right to work free from discrimination. ${ }^{2}$ In the US at least, there is some evidence that capital mobility compromises the right to organize and bargain collectively. Kate Bronfenbrenner has found that "the recent acceleration in capital mobility has had a devastating impact on the extent and nature of union organizing campaigns" (Bronfenbrenner, 2000, p.iv). Her examination of NLRB data indicates that plant-closing threats are increasingly likely to deter successful organizing and that such threats are not tied to the financial conditions of the companies involved.

Of course it is difficult to assess how much economic integration has strengthened employers' hands and how much of this is simply due to the general deterioration of labor rights in the US (Compa, 2000). Bronfenbrenner found that unions are increasingly unlikely to file unfair labor practice complaints in response to plant closing threats during organizing campaigns because they are so difficult to prove and relief is so limited under existing law. She concludes that "plant closing threats are just another tactic in their (ownership/management) anti-union campaigns, one that very effectively plays on the real fears of workers living and working in an increasingly mobile economy" (Bronfenbrenner, 2000, p.vi).

Even if increased economic integration erodes labor rights, trade policy may not be the appropriate redress. Many orthodox (neoclassical) economists and poor country elites argue that concern with labor rights in the US is just disguised "protectionism." Gary Fields argues that the list of process rights that are acceptable cross-

\footnotetext{
${ }^{1}$ Institutional economics as we understand it relies on the method of holistic "pattern modeling" in empirical research. This involves iterative case studies that seek to identify patterns of causation. See Wilber and Harrison, 1978.

${ }^{2}$ Why these should be in the "core" and not other "rights" such as health and safety or a living wage is beyond our scope here. See McIntyre (2003a) for a discussion of class interests and moral convention as discursive determinants of labor rights.
} 
culturally is actually quite short - prohibition of slavery and child labor, freedom of association, and reasonably safe working conditions. Beyond these, economies should be judged based on "outcomes oriented labor standards - employment and wage growth and these are most likely to occur with market wage determination and minimal regulation of the employment relationship" (Fields, 1990). ${ }^{3}$

Jagdish Bhagwati claims that environmental and labor standards are a purely domestic matter and should not be subjects for trade negotiations. But he acknowledges that labor standards, "unlike most environmental standards, are seen in moral terms." "In particular, it is argued that if labour standards elsewhere are different and unacceptable morally, then the resulting competition is morally illegitimate and 'unfair"' (Bhagwati, 1998, p.258).

Bhagwati argues that in the case of slavery there will be nearly universal agreement on this proposition. "...if slavery produces competitive advantage, that advantage is illegitimate and ought to be rejected" (ibid). In this case Bhagwati would support the inclusion of a "social clause" concerning labor standards in trade agreements. But, he insists, the list of "universally condemned practices such as slavery" is quite short. It is worth quoting Bhagwati at some length here.

"True, the ILO has many conventions that many nations have signed. But many have been signed simply because in effect they are not binding. Equally, the United States itself has signed no more than a tiny fraction of these conventions in any case. The question whether a substantive consensus on anything except well-meaning and broad principles without consequences for trade access in case of noncompliance can be obtained is therefore highly dubious.

Indeed, the reality is that diversity of labour practice and standards is widespread in practice and reflects, not necessarily venality and wickedness, but rather diversity of cultural values, economic conditions, and analytical beliefs and theories concerning the economic (and therefore moral) consequences of specific labor standards. The notion that labour standards can be universalised, like human rights such as liberty and habeas corpus, simply by calling them

\footnotetext{
3 Even orthodox economists sympathetic to organized labor are skeptical about including labor rights clauses in trade agreements. For instance, Richard Freeman argues that improvements in labor rights can be "paid for" through currency devaluation, or tax increases (Freeman, 1994). To the extent that international solutions are necessary he favors product labeling which allows consumers to express their preferences for "non-sweated" labor rather than imposing trade based labor standards.
} 
"labour rights" ignores the fact that this easy equation between culture-specific labour standards and universal human rights will have a difficult time surviving deeper scrutiny (ibid, pp.260-61)

That the US could see its trading rights suspended because of violations of core labor rights is clearly correct. ${ }^{4}$ It is also true that in practice core and other important "rights" are not treated as rights. As Bhagwati notes, the right to organize, protection for migrant workers, and guarantees against sweatshop conditions are weak or non-existent in the US today. As the US (with France) tends to be the chief exponent of a social clause, there is no small amount of hypocrisy here.

Bhagwati argues that positive rights, such as the right to organize and bargain collectively, can have perverse effects in a developing country context. Unionization could primarily benefit insiders who already have jobs at the expense of unemployed outsiders, and would primarily help the urban working class, which tends to be better off already than the landless poor. The latter group would be best aided through rapid growth, which, according to Bhagwati, might be hindered by urban unionization. For Bhagwati, it is growth alone that can pull the majority of workers out of absolute poverty.

"If so, the imposition of the culture-specific developed-countryunion views on poor countries about the rights of unions to push for higher wages will resolve current equity and intergenerational equity problems in ways that are normally unacceptable to these countries, and correctly so" (ibid, p.263).

In this view the alleged universality of core labor standards is incorrect, except for a few special cases (i.e., slavery) and the idea of including a social clause in trade agreements is faulty as it rejects the culturally based diversity of actually existed labor practices. The belief that the social clause is simply disguised protectionism is shared by many on the political left in developing countries. (See Kohr, 1997) 5

Bhagwati suggests that the more appropriate avenue for ratcheting up labor standards is the work of non-governmental organizations (NGOs) and the International Labor Organization. For Bhagwati, the educational activities of these organizations, to the extent they have good ideas, should be sufficient.

\footnotetext{
4 See McIntyre and Bodah (2002) for a detailed discussion of the US and ILO conventions.

5 The popular opposition to the World Trade Organization and other multilateral institutions in the developed countries contains groups who are more united by what they oppose than any particular argument in favor of international labor rights. At this time the "Seattle coalition" is more interested in organizing against the institutions of globalization than in solving concrete labor problems (Panitch, 2001).
} 
"In fact, if your ideas are good, they should spread without coercion. The Spanish Inquisition should not be necessary to spread Christianity; indeed, the pope has no troops. Mahatma Gandhi's splendid idea of non-violent agitation spread was picked up by Martin Luther King, not because he worked on the Indian government to threaten retribution against others otherwise; it happened to be just morally compelling" (ibid, p.264).

Private boycotts could also be used to create a multinational consensus in favor of labor standards. Such standards, he argues,

"should be carefully defined and formally agreed to at the ILO today in light of modern thinking in economics and of the accumulated experience of developmental and labour issues date, and with the clear understanding that we are not just passing resolutions but that serious consequences may follow for follow-through by the signatory nations. The ILO is clearly the institution that is best equipped to create such a consensus, not the GATT/WTO, just as multilateral trade negotiations are conducted at the GATT, not at the ILO" (ibid). His argument betrays a convenient naivete about the social creation of knowledge and we presume that by "modern thinking in economics" Bhagwati means his own preferred brand, neoclassical theory. But he does point out an important issue: rights are created not discovered. Rights exist only when they are embodied in laws that can be enforced by courts.

There are neoclassical economists who argue for labor standards. According to Dani Rodrik, there is "genuine discomfort...with the moral and social implications of trade." As evidence he points to the fact that members of Congress who cosponsored the Child Labor Deterrence Act were predominantly from districts with low numbers of high school dropouts. In other words, their interest in the bill stemmed primarily from the moral not the economic interests of their constituents. Rodrik believes that this demonstrates a prevailing norm under which it is "not acceptable to reduce the living standards of American workers by taking advantage of labor practices that are vastly below those enshrined in US standards" (Rodrik, 1997, p34).

The governing concept here is "blocked exchange". The Fair Labor Standards Act and the Occupational Safety and Health Act are both justified by the doctrine of blocked or "desperate" exchange, under which a market transaction will be prohibited even if the two parties agree to it, when bargaining power is wildly unequal. If someone puts a gun to my head and asks for money I may give him my wallet. A starving person may agree to sell herself into slavery. In each case, both parties have an interest in completing the transaction, but this hardly legitimates it. The Supreme Court, in the 1937 West Coast Hotel vs Parrish case, recognized that this concept 
is particularly applicable to labor markets. According to Rodrik again, "US laws since the 1930s have recognized that restrictions on 'free' contracts are legitimate in the case of unequal bargaining power.by generating an inequality in bargaining power globalization helps undermine 60 years of labor legislation and thus the social understanding those laws represent" (Rodrik, 1997, p.36).

These legal and normative concepts stand uneasily in the broad corpus of contemporary mainstream academic economics in the United States.6 But they are consistent with the institutional labor economics of John R. Commons, and with the approach to labor problems taken historically by the International Labor Organization. . Before considering the contemporary international organization of labor rights in more detail we turn to a brief summary of Commons work and its applicability to international labor problems.

\subsection{Overview of Common's Standpoint}

There is no way to convey the entirety or the subtlety of Commons's theoretical conception of the market system within the space constraints operative here. What must suffice, and hence what follows, is a highly abridged statement of Commons's relevant ideas.7

Commons saw economic activity as inherently a group phenomenon. He used the term going concern in reference to the groups within which individuals engage in ongoing coordinated activity directed to ends foreseen in the future, whether such activity involves production or the use of its fruits (consumption). An elastic concept, going concerns includes entities such as families, corporations, unions and nations among countless more. According to Commons, the transaction-"a unit of transfer of legal control"-is the basic unit of activity within the concern, one that foreshadows an agent's subsequent performance. Transactions emanate from a contest of individual wills - Commons's term for the self-directing capacities of individuals - in the context of conflicts of interest arising from self-interested individuals' desire to capture for themselves a greater share of the benefits generated by the concern's collective undertaking and to reduce the share of the collective burden they individually bear. Departing from the comforting presumption of "natural harmony," Commons embraced the Hobbesian position that disorder and disharmony are the natural

\footnotetext{
${ }^{6}$ Orthodox trade theory has become more open in recent years, with the development of imperfect competition and "eclectic" models of trade (Krugman and Obstfeld, 2001). It seems to us that acceptance of the neoclassical standpoint necessitates a doctrinal commitment to free trade as the default position however. A full consideration of this point is beyond our scope in this paper.

${ }^{7}$ For a more satisfactory overview, see Ramstad (1990).
} 
results of "free" behavior. Orderly conduct, he argued, occurs only because every concern has in place working rules-rules (including custom) establishing what individuals can, must, or may do, or not do, in their transactions with one another within the concernenforced by moral, economic, or physical sanctions. Significantly, in the absence of force, working rules will tend to be ignored by agents so long as the economic and social consequences of doing so are deemed acceptable.

Working rules objectify themselves in the actual transactions and consequent activities of a going concern's "citizens." From a legal perspective, Commons divided working rules into two types creating fundamentally different types of practices within the concern: those establishing specific rights for one class of citizens and correlative duties for another class, thereby creating authoritative practices; and those establishing zones of exposure (no rights) for one class to the liberties (no duties) carved out for another, thereby creating authorized practices.

To ensure individual compliance with the governing rules in the event it is not forthcoming willingly, every concern must have an authoritative figure, someone who is empowered to make final decisions within the concern and who has sufficient control over sanctions to obtain individual obedience to those decisions. This being the case, Commons submitted, coercion is the dominant principle underlying activity within going concerns, and organized compulsion is the true source of order within its ambit.

Yet, despite the underlying coercive structure, "required" behavior is generally experienced as forthcoming voluntarily. In the pragmatist tradition, Commons considered individuals to be institutionalized minds whose mental habits derive from the routines and practices (working rules) structuring their activities within going concerns. In his understanding, individual wills quickly or slowly adjust to the patterns implicit in working rules. That is, what working rules in fact require us to do comes to be seen as "right" or "natural" and is typically experienced as voluntary activity. Thus institutions-defined by Commons as "collective action in control, liberation, and expansion of individual action"-are the submerged dominant factor "explaining" the content of individual activity.

Despite the existence of governing working rules, conflicts of interest are not always satisfactorily contained. For example, technological evolution tends to generate new patterns of activity imperfectly governed by the existing rules. This, in turn, precipitates overt conflicts about the sharing of the burdens and benefits occasioned by the new pattern of activity that threaten to undermine order within the concern. Such conflicts are hence brought to the concern's authoritative figure for adjudication and determination of what the controlling rules are in fact to be. Thus Commons 
understood volitional institutional adjustment by authoritative figures, not the so-called price mechanism, to be the concern's true means of correlating the activities of economic agents. Significantly, the adjustment of working rules is always forward-looking and hence guided by purpose. In other words, in selecting a particular rule the authoritative figure necessarily endorses one set of envisioned future consequences as superior to another. This means that human values as to what should count most-that is, ethics-are necessarily woven into the very fabric of a concern's working rules.

As previously suggested, working rules will generally be adhered to only if there are sanctions applied to violators. Of the three principal sanctions, social disapproval, economic privation, and physical force, the latter provides the most powerful inducement. Accordingly, the party able to command superior force-in the present setting, the sovereign figure of the going concern we call the nationhas the power, outside of warfare between nations, to determine the working rules that must be adhered to under its dominion, and hence the purposes embraced by the sovereign are controlling in guiding the evolution of working rules. Believing there is no such thing as the public interest but only private interests, Common used the term public purpose in regard to a private purpose, arising out of private interests, approved of by the sovereign.

It is evident that Commons's framework has implications for some basic economic abstractions. First, the concept of an economy is simply the concept "going concern" enlarged to encompass the coordinated "economic" activity of a region, a nation, or the world when viewed as a whole. Second, the "price mechanism" is seen not as a natural process inherent in the nature of things but as an instituted pattern of interaction-an integrated network of authoritative and authorized practices-volitionally "constructed" gradually over many centuries to effectuate human purposes; accordingly, Commons appropriated as a metaphor Darwin's term "artificial selection" to indicate that human volition rather than a brute process governs the price mechanism's evolution. Third, being nothing more than the pecuniary consequences of adhering to the specific practices mandated or authorized by the controlling working rules, prices are similarly conceived as instituted phenomena. Fourth, since working rules provide a general blueprint for allocating the burdens and benefits of the concern's collective undertaken among various classes of its citizens and thereby prefigure the pecuniary consequences of adhering to those working rules, that is, market values, Commons maintained that economic values have at their root purpose-driven human volition and do not emanate from the "mechanical" operating of the price mechanism. Fifth, "competition" is understood as a zone of liberty (authorized practices) created and enforced through collective action, and as such does not 
possess a natural logic (as suggested by the institution-free model of "perfect competition") and does not "naturally" effectuate any end (such as "efficiency"). And, sixth, since there is no inherently best or natural set of working rules determining competition's concrete character, the significant question is not whether its actual form approximates an ideal conception (perfect competition) but whether it is efficacious for realizing the public purposes the working rules constituting its character were instituted to effectuate and, more importantly, whether it is efficacious for realizing the public purposes currently embraced by the sovereign.

\subsection{Commons's Theory of Reasonable Value}

Because of the central role he accorded human volition in creating the system of working rules, and because he understood those rules therefore to be a root cause of price and distributional outcomes, Commons submitted that he had worked out a volitional theory of value in contrast to the static mechanism theory utilized by neoclassical economists and the natural selection theory informing various evolutionary conceptions of the market system. In principle, of course, individual market systems (national going concerns) can consist of different working rules selected to realize different purposes. Commons coined the term "theory of reasonable value" in reference to the specific volitional underpinnings of the American market system (going concern).

Commons settled on this term because he discovered that "reasonableness" had been the dominant purpose guiding the process of authoritative dispute resolution through which English common law judges, and later the U.S. Supreme Court justices, has crafted out the system of working rules-or property rightsstructuring the price bargain, the wage bargain, and the rent bargain in the American economy of his day. By focusing on reasonableness, Commons inferred that the courts had indicated a preoccupation, first, with maintaining order and, second, with ensuring that in light of all known facts the adopted rules were as "fair to all parties concerned" as possible. In other words, Commons discovered that "fairness" was a primary purpose toward whose realization the American market system had been volitionally instituted. Accordingly, by deciding that a particular working rule was reasonable and hence should be adopted, common law judges and courts had consecutively indicated a belief that market prices resulting from adherence to it would consequently be "fair" or "just" ones. As a result, Commons inferred that fairness was intended to characterize the transactional outcomes known as price, wage, and rent bargains. Hence he used the term "reasonable value" as a 
descriptive term in reference to market outcomes in the American economy.

The issue of what "fairness" entails is a deep one. Commons discerned that in the minds of justices deciding disputes over the many centuries during which the market system was gradually instituted, "fair" generally meant little more than "customary." Of course, disputes invariably require judges to assess tradeoffs between various established practices and the various "good" consequences they facilitate. In assessing such tradeoffs, Commons insisted, the class bias of judges, who have overwhelmingly come out of the propertied classes, has inevitably colored their judgment. Deeply committed to the idea that all humans have the "citizenship" potential to participate as equals in their own governance, that is, in the process of institutional adjustment, Commons equated social progress with the synthesis of an ever-broadening set of private interests into the public purposes guiding the ongoing process of institutional adjustment (as putatively occurs with representative democracy). Accordingly, Commons envisioned a future in which working rule adjustments affecting price, wage, and rent bargains would emanate from a collective will that equally accommodates or synthesizes the conflicting private interests typical of all classes of "citizens" within the concern. In other words, for Commons the operative meaning of "fair" should be "agreed to without coercion by all affected parties."

Thus a regime of truly Reasonable market values presumes working rules that are "fair" in the sense that they have been agreed to without coercion by the most directly affected parties. This, of course, is precisely what is approximated by collective bargaining between a corporation and a union representing its workers. However, Commons gradually lost faith that unions could successfully organize a majority of the work force and helped in Wisconsin to institute a quasi-corporatist "statist" solution to the problem. That solution was the Wisconsin Industrial Commission, established in 1911 to oversee the evolution of working rules affecting the real wage (this includes working conditions) obtained by industrial workers in Wisconsin. Viewing the Wisconsin experiment as successful, Commons proposed that the "fourth branch of government," the regulatory commission, could be similarly utilized to oversee the evolution of labor market working rules at the national level as well.

According to Commons, a regulatory commission will be able to work out truly Reasonable compromises to the disputes brought before it, and thereby contribute to the production of truly Reasonable market values, only if it consists of an equal number of self-selected members from the two principal opposing interests, ones who actually understand the tradeoffs involved from inside the 
class mentality, who in turn would be required to agree on one or more additional members who would serve as tie-breakers. To put the issue the other way, no members should be appointed to represent the strictly hypothetical "public interest." Needless to say, this makes Commons's proposal significantly different from the course actually chosen in the United States. Commons further proposed that regulatory commissions be given only a broad mandate by legislative bodies-for example, a mandate to establish and maintain "reasonable working standards," and that they be left free to work out for themselves the practices that correspond to this standard. In addition, Commons urged that when searching for a model of "the possible" the commissions should limit themselves to practices already shown to be practical by evidence of their adoption by economically viable concerns and avoid the ideal, economically untested prescriptions of "experts." Those practices would then be made mandatory for all.

Before proceeding further with the discussion of the regulatory commission's role in effecting economic progress, it may be best first to review Commons's conception of labor markets.

\subsection{Commons's Analysis of the Labor Market}

Like many in his generation, Commons embraced Henry Carter Adams's contention that competitive labor markets were plagued by "destructive competition." In this view, when there is some degree of redundancy in labor supply competition among workers drives all toward the lowest common denominator-or in Commons's terminology, toward the standards of the "least conscientious" employers. Where international trade is concerned, Commons argued, labor supply premised on "offer prices" tied to vastly different prevailing standards of living reinforce this downward tendency.

Commons revealed greater insight into the logic of "destructive competition" in his famous article showing how "extension of the market," which Adam Smith had glorified as the generator of productivity increases, changed the nature of the "labor market" faced by American shoemakers and, in consequence, the protective devices they pursued to shelter themselves from the unwanted "competitive menace" (see Commons 1909). As the product market served by shoe makers moved from (1) the custom order stage (a personal market in which the consumer purchased directly from itinerant shoemakers) to (2) the retail shop stage (a local market in which consumers could purchase either directly from itinerant shoemakers or from a local retain establishment supplied by the same shoemakers) to (3) the wholesale order stage (a regional market supplied by full time shop workers who never dealt directly with 
consumers, but one in which production was always preceded by an order from a specific retailer) and finally to (4) the wholesale speculative state (a regional, national, or even world market in which production precedes the decision of a retailer to place an order). These stages are recapitulated in Figure 1, shown on the next page.

In the initial stage of this evolutionary process, the actual producer (shoemaker) dealt directly with the eventual user of the product (consumer) and simultaneously negotiated a satisfactory price and an implicit wage. The fundamental conflict of interest involves the interest of the consumer in a lower price and the interest of the worker in a higher wage and better conditions of work. When consumer and producer were bargaining equals, neither was able to exercise control over the price bargain (which included agreement about the quality of the shoe to be produced) and thereby implicitly the wage bargain. When the retail shop stage appeared, the worker began to lose control over both the price bargain and the quality of the shoe, which were now decided through negotiations between the consumer and the retailer. Thus the producer's role became limited to negotiating a supply price with the producer for footwear of the type and quality the customer desired. Objectively, the retailer now became an employer and the producer a wage worker. Still, as the actual work was not performed until the consumer negotiated a specific order from the retailer, the producer maintained some negotiating power regarding the wage bargain since the retailer continued to possess limited power to pass a higher wage on to the consumer through a higher price or lowered quality.

When the wholesale order stage emerged, the producer was placed in an even weaker position in regard to his ability to maintain satisfactory wages. Now there were two price bargains in which the producer did not participate, the first between the customer and the retail merchant followed by another between the retail merchant and the wholesale merchant. The wage bargain, in turn, was now negotiated between the wholesaler and the producer. With this stage the producer lost any control over the quality of the product and became a piece worker. Still, because work was initiated only after both price bargains had been negotiated, the worker continued to possess some degree of power over the wage negotiation, since a higher price could potentially be passed forward to the customer via the price bargain. However, if workers, now preoccupied with the wage bargain, demanded a wage increase after an order was taken, that is, after the price bargain between the wholesaler and the retailer had been negotiated, a direct conflict of interest resulted between the wholesale merchant and the producer, wherein the wholesale merchant's own interest necessitated that he oppose the workers' demand. It is at this stage, in other words, that the 
employer function comes to the forefront and where, Commons argued, we see the origins of the conflict between capital and labor.

\section{Figure 1}

\section{Evolution of the Wage Bargain \\ (Shoemakers Article)}

Two bargains: P - Price Bargain (Exchange of ownership of a produced good) W - Wage Bargain (Exchange of ownership of labor power)

Ultimately, the central conflict is between the interest of the consumer in a lower price and the interest of the worker in a higher wage and better conditions of work. The issue is: who has the advantage?

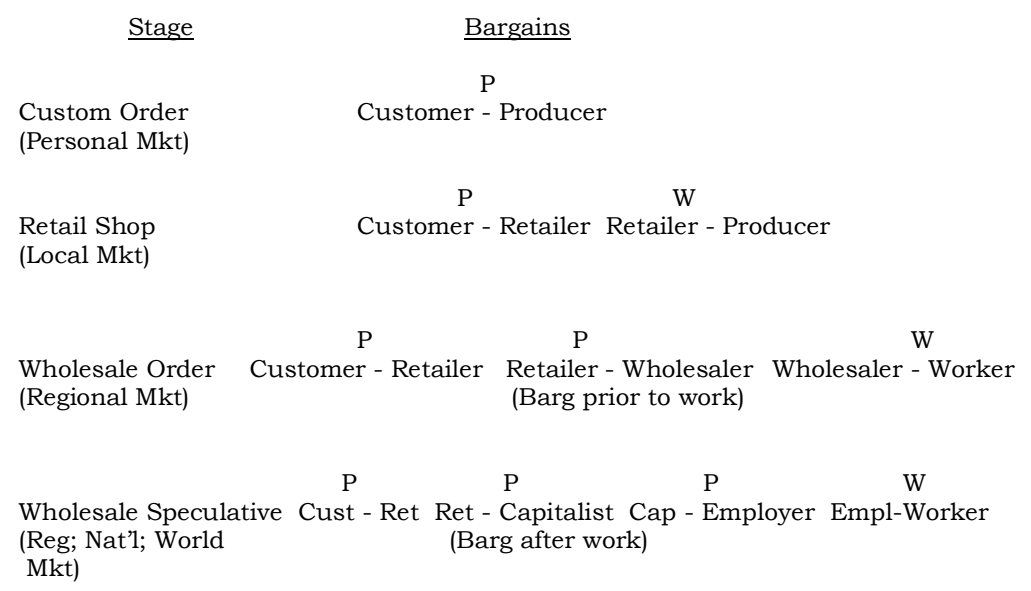

At all stages, workers seek "protective device" from "competitive menace"

(1) protective organization (e.g., unions)

(2) protective legislation (e.g., labor "standards")

With the advent of the wholesale speculative stage, the producer becomes completely subordinated to the consumer and the phenomenon of destructive competition is born. Now there are three price bargains: first, between the customer and the retail merchant; second, between the retailer and the capitalist merchant organizing the distribution of a specific shoe; and third, between the capitalists manufacturing firms who can only obtain a profit margin by means of "sweating" the worker or cheapening work. With this stage, the 
capitalist merchant takes on the role of the wholesale merchant but adds the function of maintaining stock in anticipation of orders from retailers. To acquire and maintain that stock, the capitalist merchant negotiates the first price in the chain, a supply price from the manufacturer who, being compelled to compete vigorously with other manufacturers, can raise its profit level only by finding ways to reduce the costs of producing the agreed upon output, primarily by specializing in reducing the cost of its labor "input" per unit of output. Subsequently, the capitalist merchant negotiates a price bargain with a retail merchant but must bear the risk of being stuck with stock that cannot be sold at a price allowing for recovery of the previously negotiated price with the manufacturer and also the other necessary costs of doing business. The retail merchant, of course, is limited in his bargaining with the wholesaler by the knowledge that the consumer is ultimately the controlling party in the price bargain between the consumer and the retailer.

What is significant here is that with this fourth stage of the shoemakers labor market, complete separation between consumer and producer has occurred, with the former possessing complete control, ultimately, over the wage bargain's upper limit. The manufacturer profits by driving the wage bargain below that limit. That is, the manufacturer profits by advancing the process earlier referred to as destructive competition. Competition between producers requires that all adopt the same methods or be driven out of business.

\subsection{The Theory of Reasonable Value (continued)}

If labor is allowed to compete "freely," that is, without restrictions, destructive competition-the gradual spread throughout the labor market of the least costly practices-is the inherent tendency if there is redundant labor. It is the role of labor standards to prevent that downward spiral and thereby to preserve socially acceptable labor market outcomes. Equally important, at the bottom of the labor market-and, to a lesser extent at higher levels, especially in regard to working conditions-improvement of the worker's situation occurs through a raising of those standards, or as Commons put it, by "raising the plane of competition." The regulatory commission, as conceived by Commons, provides a governance structure through which destructive competition can be avoided and the plane of competition-and thereby attainments-in the labor market can be raised. Equally important, its composition allows workers, understood as "citizens" of their concerns with equal rights of self-determination rather than as "owners" offering a commodity (themselves) for sale, to participate as equals in the 
process of determining which working rules, that is, which labor standards, are at any given time considering the tradeoffs involved the "best" ones attainable. Therein, a just compromise between the divergent interests of the employer for higher profits and the worker for higher wages and better working conditions can be worked out and objectified in the adopted working rules. And the market values resulting from adherence to those rules will truly be Reasonable ones-as good as practicable for now.

\section{International Organization of Labor Rights}

In terms of figure 1 , the increased international integration of the last several decades has lengthened the bargaining chain between producers and consumers. Moreover, it has weakened the effectiveness of national systems of labor regulation. In this section we examine the extent to which the International Labour Organization might act as an authoritative institution for global bargaining chains.

Our point is not to show that, in each and every instance, the ILO fits (or does not fit) the Commons framework. Such an exercise would be both endless and pointless. Rather, we will show that in its chief purposes and overall organization, the ILO is consistent with Commons standpoint, his theory of reasonable value, and his analysis of labor markets. In the closing section we examine some of the implications of this consistency.

The initial impetus for international labor legislation and an international labor organization came as a response to the human costs of the industrial revolution. Its prime movers were intellectual elements of the 19th century middle class: industrial managers, politicians, public health physicians, utopian socialists and reform economists. Three goals drove these groups: humanitarian concerns, desire for social peace, and the desire to counter destructive competition. 8

These three motivations were reflected in the 1919 preamble to the ILO's constitution, in the 1944 Philadephia declaration which spelled out the organization's goals for the post World War II period, and in the ILO's current programs promoting "core" labor standards. While the prevention of destructive competition is the most clearly consonant with Commons' standpoint, the notion that "universal and lasting peace can be established only if it is based upon social justice" is also at the heart of Commons vision (ILO, 1919, preamble).

8 This section draws on the following histories of the ILO: Barnes, 1926, Ghebali, 1989, Alcock, 1971, Shotwell, 1934, Turmann, 1922. 
In the Philadephia declaration, the ILO reaffirmed and extended these concerns as its primary motivations:

1. "Labour is not a commodity"

2. "Poverty anywhere constitutes a danger to prosperity anywhere"

3. "All human beings...have the right to pursue both their material well-being and their spiritual development in conditions of freedom and dignity, of economic security and equal opportunity"

4. "Freedom of expression and association are essential to sustained progress" (ILO, 1944)

The declaration goes on to enumerate conditions concerning wage, hours, employment, working conditions and other particular matters that it seeks to achieve. But these goals are all meant to be the concrete embodiment of the concerns listed above.

The third and fourth goals require some comment. By mentioning spiritual development, the ILO creates a somewhat larger conception of human activity than is common in mainstream economics. However, this is perfectly consistent with Commons view that material abundance and leisure time were means to more fundamental human goals. And while in his later work Commons called these goals "independence" and "responsibility," it is also the case that there was a significant element of Christian socialism and Social Gospel in the foundations of Commons thought (Commons 1934 a and b, Ramstad, 2001).

The emphasis placed on freedom of expression and association, which clearly remain the most important of the ILO's "core" labor rights, is also central to Commons. ${ }^{9} \mathrm{He}$ saw the regulatory commission as the preferred instrument for settling disputes over working rules that were sure to occur within the evolutionary process of social change. Such commissions, he argued should be populated be representatives of the opposing interests, not by people supposedly representing the public interest. So without freedom of expression and association, the primary body for adjudicating disputes could not exist, at least in the way that Commons envisioned it. These principles and practices continue to guide the ILO today in responding to the increasing international integration of our own period. In fact, in answering the question why international labor standards are needed today, the ILO's website starts with the statement on destructive competition from the Preamble to its constitution:

\footnotetext{
9 The conventions on freedom of association are the most widely ratified. The special Committee on Freedom of Association occupies a unique place within the ILO's subsidiary bodies and with its 3-3-3 makeup is the most truly tripartite and perhaps most effective of those bodies.
} 
"...the failure of any nation to adopt humane conditions of labour is an obstacle in the way of other nations which desire to improve the conditions in their own countries" (ILO, 1919).

In the 1997 report, "The ILO, Standards Setting and Globalization," the director general writes "This liberalization of trade carries the risk, as the Preamble to the Constitution of the ILO warns us, that international competition, by inhibiting the will of certain members to introduce progress, might be an obstacle in the way of other nations which desire to improve the conditions of their own countries'" (ILO, 1997). This and other recent documents restate the priority given to social justice and commit the ILO to work with member states to strive for it in the new economic conditions.

Is the ILO then an authoritative figure in the Commons sense? It falls short on several counts. First, despite its explicit commitment to tripartism, national delegations are made up of two government representatives and one each from labor and capital. Thus the "public interest" has more weight than Commons would have given it. This is particularly the case as many delegations from poor countries sometimes find it hard to send full delegations. If public representatives are simply two more votes for the interests of capital, in what sense can tripartism really be thought to function? The evidence here is unclear. It appears to be the case that the nongovernmental groups maintain strong separate identities because they are effectively organized by the International Confederation of Free Trade Unions and the International Organization of Employers. The employers group has been concerned with the feasibility of standards and has often desired to slow down standard setting so as to update and consolidate the existing standards. The workers' group has opposed this. The government group is less homogeneous and tends to be most influential when employers and workers are split. 10

Second, the ILO has attempted to maintain itself as both a tripartite and universal institution. But tripartism is a European concept that evolved from the particular experience of Europe's industrialization. It may have little applicability outside Europe and the industrialized countries settled by Europeans. And indeed, Commons own views of reasonable value were developed by a reading of Anglo-American legal history. Thus what might be reasonable for Europe, England or the US may be by no means reasonable elsewhere. The notion that the ILOs principles are applicable to "all people everywhere," as the Philadephia declaration states, simply looks past very real differences on what might constitute reasonableness.

The ILO has handled these contradictions in theory by considering social justice as a tendency and not a state. In practice,

10 See the discussion in Ghebali, ch.4. These patterns were confirmed in interviews conducted with ILO staff in Geneva, Nov.2002. 
countries have been allowed some degree of flexibility in adopting conventions. Regional standards were rejected, as "sub-standards for sub-humans." (Ghebali, 205). States can define the obligations of the limits they will assume within the confines of the convention. Flexibility is also sometimes achieved through general wording such as "appropriate," "adequate," or "promote." Flexibility has not been granted in the conventions dealing with core human rights or in those instruments dealing with unfair international competition however.

The industrialized market economies see themselves as guardians of the ILO's conscience, and their employer and worker groups are clearly influenced by Western concepts of freedom. Upon joining the ILO after World War II, the post-colonial countries argued that underdevelopment hampered the implementation of standards. For instance, freedom of association might cause expensive social unrest and political agitation. At the 1984 conference the developing countries renewed this argument, and called for looking at the structural rather than the formal causes of failure to abide by conventions. This led the conference to move toward allowing for the heterogeneity of its member states during the formulation rather than in the enforcement of labor standards. These differences reflect a wider split over what constitutes rights. "Western" countries, and particularly the United States, have been most apt to recognize socalled "first generation" rights, the civil rights of the individual. Developing countries and European social democracy have tended to emphasize second generation rights, economic rights (Meyer, 1998, ch.1). For the ILO, as for Commons, this tension is resolved by emphasizing what we might call process rights. The rules by which the social product is produced are privileged over questions concerning ownership and distribution. ${ }^{11}$

Third, the process by which standards are enforced does not involve economic sanctions or the threat of violence, which Commons thought, was ultimately necessary for an authoritative institution. Employers or workers groups can make presentations against governments that can result in moral sanctions. Most governments tend to cooperate and adopt reforms before the formal complaint process is completed, so apparently the procedure has some impact. But there is also reason to believe that many complaints are not formally brought forward, because workers organizations don't want to deter states from ratifying additional conventions, or because they do not want to embarrass friendly governments. Thus there may be

11 The most effective transnational rights networks have been those dealing with equality of opportunity and bodily harm. See Keck and Sikkink (1998), especially ch.6. International labor rights, as conceived by the ILO, fall partly within these categories but also include collective rights that sit uneasily within these essentially liberal categories. See McIntyre (2003b). 
some thing to Bhagwati's claim that some conventions have been ratified only because it is known they will not be enforced. In its core values and organizational structure, the ILO is consistent with Commons standpoint and indeed much closer to that standpoint than any other international organization of which we are aware. However, it does not incorporate the full range of viewpoints necessary to succeed as a Commons type regulatory commission, its proclaimed universality flies in the face of Commons presumption that core values are worked out over time through a process of judicial review, and it lacks necessary enforcement capabilities. The ILO does embody a formal organization and an attitude to social justice that might let it evolve into the kind of organization necessary to regulate the increasingly long chains of bargaining in the international economy. How such an evolution might come about would take us far beyond the bounds of this paper. However, having surveyed the institution's weaknesses from a Commons perspective, we conclude with two suggestions.

\section{The ILO and Reasonable Value}

Contrary to Bhagwati, we do not believe the ILO would benefit much from "modern thinking in economics." Such thinking, in its purely neoclassical version, is both directly contradictory to the ILO's core values and organizational framework. It is also deeply embedded in the other major international economic organizations, the World Bank and especially the International Monetary Fund, organizations that directly undermine the ILO's mission in many developing countries. ${ }^{12}$

To see the first point clearly, consider Figure II:

$$
\text { Neoclassicals Commons/ILO }
$$

$\begin{array}{lll}\begin{array}{l}\text { Purpose of } \\ \text { moral Economic Life }\end{array} & \text { maximize individual utility } & \begin{array}{l}\text { secure economic and } \\ \text { security }\end{array} \\ \text { Price } & \begin{array}{l}\text { automatically determined by } \\ \text { market forces }\end{array} & \text { instituted } \\ \text { Markets } & \text { produce optimality and } & \begin{array}{l}\text { site of authorized } \\ \text { social harmony } \\ \text { practices transferring } \\ \text { ownership and conflict } \\ \text { over those practices }\end{array} \\ & & \begin{array}{l}\text { prone to destructive } \\ \text { competition }\end{array} \\ \text { Labor markets } & \begin{array}{l}\text { like other markets; some } \\ \text { possibility of market failure }\end{array} & \text { Inevitably intertwined }\end{array}$

12 The economists we interviewed at the ILO indicated without hesitation that their theoretical orientation was institutional. This sometimes leads to difficulty in communicating with economists at the other international organizations. 
If by "modern economic thinking" Bhagwati means neoclassicism, he might as well ask the ILO to close up shop. If, on the other hand, he means the "new information economics," or "new institutional economics" then he would have the ILO adopt an analytical framework that, at its best, has rediscovered some of Commons insights by using neoclassical assumptions, and even then is inconsistent with the economics of the other major international organizations. Space limitations prevent us from a full consideration of this issue. ${ }^{13}$ But there is no question that the "new institutional economics," if adopted by the ILO, would not bridge the gulf between the ILO, the Bank, and the Fund. This is seen most clearly in the writings and career of one of the leaders of this school, Joseph Stiglitz, who was fired from his position as chief economist at the Bank for questioning the conventional wisdom (Wade, 2001.)

In his dissent to the Meltzer commission report on reforming the international financial institutions, Jerome Levinson makes it clear that the World Bank and the International Monetary Fund are actively involved in undermining the social norms behind labor rights. The Bank claims to be "analyzing the effects" of freedom of association and collective bargaining "in order to form an opinion." The Bank claims that incorporating core labor rights into its decision making inserts a political dimension which is a violation of the Bank's charter (Levinson, 2000.) 14

The Bank regularly encourages loan recipients to increase "labor market flexibility" which they are able to believe is not a political directive, although in practice increased flexibility makes it easier for firms to fire workers and makes it harder for unions to negotiate on behalf of their members.

The founders of the Bretton Woods institutions, John Maynard Keynes and Harry Dexter White, clearly saw the protection of Labor's interests as a precondition for liberalizing trade and finance (Helleiner, 1994). Indeed, the original charter for the International Labor Organization had an entire chapter devoted to labor standards and trade.

Stiglitz, former Bank chief economist, wrote that "when labor issues came up at the Bank they did so mainly within a narrowly economic focus and even more narrowly through the lens of

\footnotetext{
${ }^{13}$ Kaufman and Hotchkiss (2000) present the "new institutional school" as the fourth generation of institutional thought following from the founders (Commons, Veblen, etc.), the neo-institutionalists (Kerr, Lester, etc.) and dual labor market theory (Piore, Doeringer, Bluestone). It uses neoclassical efficiency concepts to explain institutional characteristics of labor markets. Whether and to what extent this school is within the institutional tradition is beyond the scope of this paper but see Hillard and McIntyre (1994). For an analysis that sees many of these developments as neoclassical theory's increasing ability to deal with non-neoclassical critics, see Boyer and Smith (2001).

14 More recently the Bank has published a report that is more favorable to trade unions (World Bank, 2003). It is not clear what impact this will have on policy.
} 
neoclassical economics; a standard message was to increase labor market flexibility - the not so subtle sub-text was to lower wages" (Stiglitz, 2000, p.1). In any institutionally and historically informed view, the design of a labor relations system is more than a process of achieving optimum (i.e. blackboard) efficiency. Rather, it is the result of a long history of social conflict in which political, natural and cultural factors interact with a variety of economic considerations, including but also well beyond efficiency. If one accepts the Commons/Hobbesian view, then the labor relations system is best seen as an integral component of the social compact and should not be treated as if it were the result of a blackboard-engineering problem.

For instance, just a bit of historical sensitivity might have alerted IMF and World Bank economists to the possibility that market liberalization and privatization of state assets would lead to social distress. Since a strong labor movement is often at the forefront of movements for social justice, Stiglitz now argues that liberalization and privatization might wisely have been accompanied by strengthening of unions and other labor market institutions (Stiglitz, 2000). Of course, Stiglitz was fired for this and other violations of the Washington consensus (Wade 2001).

In both the World Trade Organization and Free Trade Area of the Americas negotiations, US negotiators have argued for stronger action on labor rights but they have not made this a priority. Yet Congress has already legislated that recipient countries must effectively assure core worker rights. In 1995 Congress passed the Sanders/Frank amendment, requiring the Treasury to direct US representatives to these institutions to use their "voice and vote" to encourage both the institutions and borrowing countries to respect core worker rights as an integral part of their structural adjustment programs. In approving the US quota increase for the IMF in 1998, Congress added the requirement that worker rights not be undermined by Fund or Bank mandates for "labor market flexibility."

Though the will of Congress is clear, these policies have never been implemented. The US representatives to the Fund and the Bank have never voted against financing governments that are notorious abusers of core labor rights. One problem is that the Treasury guides policy in this area and the Treasury has made assisting the security and mobility of capital its main goal since the 1970s (Helleiner, 1994).

Levinson proposes giving the Labor Department a greater role in certifying labor policies under Sanders/Frank, allowing nongovernmental organizations to file Sanders/Frank petitions, and using ILO documents in findings. He also argues for amending the WTO charter to include core labor rights. 
The use of ILO materials in findings of US law would be helpful in promoting the ILO as an authoritative figure. The ILO, because of tripartism, is a preferred format for designing working rules for international labor rights. The ILO is the only international organization that is tripartite, even if its practice is not as strong as its principle. The promotion of the ILO as an arbiter of authoritative and authorized practices would serve as a counterweight to the IMF and World Bank. Promoting the ILO as a "regulatory commission for international labor problems" is a sound idea given the Commons vision.

The ILO could become and to some extent already is the place where the meaning of organizing concepts such as reasonable and fairness can be debated and confronted with other such concepts. It should, in our view, be promoted as an authoritative institution, particularly in dealing with labor aspects of international economic activity between countries at markedly different social and economic characteristics.

Levinson's suggestion that non-governmental organizations should be able to petition under Sanders-Frank is also a good one. This builds on experience with the North American Agreement on Labour Cooperation. Upholding a slightly broader definition of core labor rights than the ILO, NAALC and its commissions and offices have been a modest success. It has promoted a variety of cooperative activities for scholars and the social partners, which has promoted cross-border labor solidarity in the region. It has taken and heard cases that have promoted transparency in labor law administration in all countries. Not only has NAALC helped to strengthen Mexico's enforcement of its own labor laws in some cases, it has given labor organizers another avenue to highlight declining human and labor rights in the US. This is not to say that NAALC or the EU's social clause can substitute for other forms of international labor regulation. But the "sunshine effect" of these cases certainly contributes to rising public awareness and debate, and ultimately to organizing and political pressure. And by providing more examples of "the possible," such cases may provide a rich pool of examples for dealing with international labor disputes in a world of uneven economic development.

Strengthening the ILO as an authoritative international institution while broadening access to decision making in regional agreements are appropriate responses to the unevenness of the development of capitalism over the last several decades. Economic life has become both globalized and regionalized. Industrial relations scholars used to believe in the convergence of systems, and that view may still have some validity, especially within the European Union. But "globalization" has not eliminated all differences between national systems and even in Europe some form of super-national 
regulation is necessary. This is all the more applicable to North America and especially to FTAA, to say nothing of the overwhelmingly difficult problem of producing agreement on reasonable value across the countries making up the WTO.

Ultimately, we would hope that, through the promotion of the ILO as an authoritative institution on international labor problems, that the WTO would come to accept some version of ILO core labor rights into its charter. In the Philadephia declaration, the ILO stated that all international economic policies should be judged in terms of their impact on the right of all human beings "to pursue both their material well-being and their spiritual development in conditions of freedom and dignity." If international economic integration is not to lead to international social disintegration, it seems to us that the powerful effects of destructive competition must be restrained.

\section{References}

Alcock, A., (1991), History of the International Labour Organization, London: MacMillan, 1971.

Barnes, G., (1926), History of the International Labour Office, London: Williams and Norgate, 1926.

Bhagwati, J., (1998), A Stream of Windows: Unsettling Reflections on Trade, Immigration and Democracy, Cambridge: MIT Press, 1999.

Borjas, G., R. Freeman and L. Katz, (1997), "How Much do Immigration and Trade affect Labor Market Outcomes?" Brookings Papers on Economic Activity, pp.1-67

Boyer G. and R. Smith, (2001), "The Development of the Neoclassical Tradition in Labor

Economics," Industrial and Labor Relations Review, 54, 2.

Bronfenbrenner, K., (2000), Uneasy Terrain: The Impact of Capital Mobility on Workers, Wages, and Union Organizing, Washington: US Trade Deficit Review Commission.

Commons, J.R., (1934a), Institutional Economics: Its Place in Political Economy, New York: MacMillan, 1934a. , (1934b), Myself, New York: MacMillan, 1934b

Compa, L., (2000), Unfair Advantage: Workers' Freedom of Association in the United States under International Human Rights Standards, New York: Human Rights Watch.

Freeman, R., (1994), "A Hard Headed Look at Labor Standards," in W. Sengenberger and D. Campbell, International Labor Standards 
and Economic Interdependence, Geneva: Institute for International Labour Studies.

(1996), "Towards an Apartheid Economy," Harvard Business Review, vol.74, 5, Sept.-Oct.

Fields, G., (1990), "Labor Standards, Economic Development and International Trade: Conceptualizing Labor Standards and Government's Role in Promoting Them." In Labor Standards and Development in the Global Economy, Washington: US Department of Labor, Bureau of International Affairs.

Ghebali, V.Y. (1989), The International Labour Organization: A Case Study of the Evoluton of UN Specialized Agencies, Dordrecht: Martinus: Nijhoff, 1989.

Helleiner, E., (1994), States and the Reemergence of Global Finance: From Bretton Woods to the 1990s, Ithaca: Cornell.

Hillard, M. and R. McIntyre, (1994), "Is There a New Institutional Consensus in Labor Economics?", Journal of Economic Issues 28, no. 2.

ILO, (1919), Constitution.

http://www.ilo.org/public/english/about/iloconst.htm

ILO, (1944), The Philadephia Declaration,

http://www.ilo.org/public/english/about/iloconst.htm\#annex

ILO, (1997), The ILO, Standard Setting and Globalization. Report of the Director-General,

http://www.itcilo.it/english/actrav/telearn/global/ilo/law/ilodg.htm

Kaufman, B. and J. Hotchkiss, (2000), The Economics of Labor Markets, Fort Worth, Dryden.

Keck, M. and K. Sikkink, (1998), Activists Beyond Borders: Advocacy Networks in International Politics, Ithaca: Cornell.

Kohr, M., (1997), "The WTO and the Battle over Labor Standards," www.globalpolicy.org/socecon/labor/wtolabor.htm.

Krugman, P. and M. Obstfeld, (2001), International Economics, New York: Addison Wesley.

Levinson, J. "Dissenting Statement," (2000), Report of the International Financial Institutions Advisory Commission, www.house.gov/jec/imf/ifiac.htm

McIntyre, R., (2003a), "Class, Convention, and Labor Rights: Marxian and Institutional Perspectives on International Labor Problems," presented to the conference on the Future of heterodox economics, Kansas City, June 7, 2003. 
, (2003b), "Globalization, Human Rights, and the Problem of Individualism," Human Rights and Human Welfare, Winter 2003, pp.1-14,http://www.du.edu/gsis/hrhw/volumes/2003/3-

$1 /$ mcintyre3-1.pdf (b)

McIntyre, R. and M. Bodah, (2002), "The US and ILO Conventions No. 87 and No. 98: The Freedom of Association and Right to Bargain Collectively," AFL-CIO/Michigan State University, Worker Rights Conference, East Lansing, Michigan, October 11, 2002

Meyer, W., (1998), Human Rights and International Political Economy in Third World Nations: Multinational Corporations, Foreign Aid, and Repression, Westport: Praeger.

Panitch, L., (2001), "Reflections on Strategy for Labor," in Working Classes, Global Realities: Socialist Register 2001, edited by Leo Panitch and Colin Leys with Greg Albo and David Coates, NY: Monthly Review.

Polanyi, K., (1980) [1944], The Great Transformation: The Political and Economic Origins of Our Time, Boston: Beacon.

Ramstad, Y., (2001), "John R. Commons Reasonable Value and the Problem of Just Price," Journal of Economic Issues, June 2001.

, (1990), "The Institutionalism of John R. Commons: Theoretical Foundations of a Volitional Economics," W.J Samuels, editor, Research in the History of Economic Thought and Methodology, vol.8, pp.53-104.

Rodrik, D., (2000), "How Far Can International Economic Integration Go?” Journal of Economic Perspectives, Winter.

, (1997), Has Globalization Gone Too Far? Washington: Institute for International Economics.

Shotwell, J., (1934), The Origins of the International Labour Organization, New York: Columbia.

Silver, B., (1994), "Labor Movements from a Global Perspective," www.jhu/ igscph/win94sil.htm).

Stiglitz, J., (2000), "Democratic Development as the Fruits of Labor," Keynote Address, Industrial Relations Research Association, Boston MA, January 2000

Turmann, M., (1922), "The Christian Social Movement and International Labour Legislation," International Labour Review, VI:I, 1922.

Wade, R., (2001), "Showdown at the World Bank," New Left Review, Jan.-Feb. 
Wilber, C. and R. Harrison, (1978), "The Methodological Basis of Institutional Economics: Pattern Model, Storytelling, and Holism," Journal of Economic Issues 12, March, pp. 61-89.

Wood, A, (1995), "How Trade Hurts Unskilled Workers," Journal of Economic Perspectives, 9 no.3, pp. 57-80

World Bank, (2003), Unions and Collective Bargaining: Economic Effects in a Global Environment, Washington D.C. 